\title{
Degenerative xanthate transfer to olefins under visible-light photocatalysis
}

\author{
Atsushi Kaga, Xiangyang Wu, Joel Yi Jie Lim, Hirohito Hayashi, Yunpeng Lu, \\ Edwin K. L. Yeow* and Shunsuke Chiba*
}

\author{
Full Research Paper \\ Address: \\ Division of Chemistry and Biological Chemistry, School of Physical \\ and Mathematical Sciences, Nanyang Technological University, \\ Singapore 637371, Singapore \\ Email: \\ Edwin K. L. Yeow* - edwinyeow@ntu.edu.sg; Shunsuke Chiba* - \\ shunsuke@ntu.edu.sg \\ * Corresponding author \\ Keywords: \\ energy transfer; olefin; photocatalysis; radical; xanthate
}

\author{
Beilstein J. Org. Chem. 2018, 14, 3047-3058. \\ doi:10.3762/bjoc. 14.283
}

Received: 28 September 2018

Accepted: 28 November 2018

Published: 13 December 2018

This article is part of the thematic issue "Reactive intermediates part I: radicals".

Guest Editor: T. P. Yoon

(C) 2018 Kaga et al.; licensee Beilstein-Institut.

License and terms: see end of document.

\begin{abstract}
The degenerative transfer of xanthates to olefins is enabled by the iridium-based photocatalyst $\left[\operatorname{Ir}\left\{\mathrm{dF}\left(\mathrm{CF}_{3}\right) \mathrm{ppy}\right\}_{2}(\mathrm{dtbbpy})\right]\left(\mathrm{PF}_{6}\right)$ under blue LED light irradiation. Detailed mechanistic investigations through kinetics and photophysical studies revealed that the process operates under a radical chain mechanism, which is initiated through triplet-sensitization of xanthates by the long-lived triplet state of the iridium-based photocatalyst.
\end{abstract}

\section{Introduction}

A degenerative radical transfer of xanthates to olefins has been developed as a robust synthetic tool to create new $\mathrm{C}-\mathrm{C}$ and $\mathrm{C}-\mathrm{S}$ bonds in a single operation [1-13]. The method is featured by not only its capability of introducing a wide range of carbon substituents but also the ability of the installed xanthyl group in being transformed into a variety of functionalities [1-14]. This concept has also been of particular importance in the field of polymer science, known as reversible addition-fragmentation chain transfer (RAFT) polymerization [15,16]. Mechanistically, the degenerative transfer of xanthates 1 to olefins 2 proceeds through a radical chain mechanism, and thus requires an initial formation of carbon radicals $\mathbf{A}$ that add onto olefins 2. The subsequent reaction of the resulting alkyl radicals $\mathbf{B}$ with xanthates $\mathbf{1}$ provides xanthate adducts $\mathbf{3}$ with generation of carbon radicals $\mathbf{A}$ that maintain the radical chain (Scheme 1A). Peroxide initiators such as dilauroyl peroxide (DLP) are commonly utilized [1-14], while decomposition of DLP needs a high reaction temperature and inevitably generates considerable amounts of byproducts derived from DLP that sometimes require tedious purification of the desired products. A combination of triethylborane $\left(\mathrm{Et}_{3} \mathrm{~B}\right)$ and molecular oxygen can also initiate the reaction at lower temperature (e.g., room tempera- 
ture), while the employment of $\mathrm{Et}_{3} \mathrm{~B}$ is hampered due to its pyrophoric nature under aerobic conditions as well as undesired $\mathrm{Et}_{3} \mathrm{~B}$-mediated dexanthylation of $\alpha$-xanthyl ketones [1721]. As an alternative strategy, a light-driven approach has been developed [22-26], since the first degenerative transfer of xanthates using $S$-benzoyl $O$-ethyl xanthate as a photo-cleavable initiator under tungsten lamp irradiation was reported by Zard $[25,26]$ (Scheme 1B). However, these protocols have thus far adopted energy intensive light sources. Therefore, there is still ample room for establishing new protocols to realize the degenerative transfer of xanthates onto olefins under userfriendly and milder reaction conditions. Herein, we report a photocatalytic degenerative radical transfer of xanthates to olefins using an iridium-based photocatalyst under blue LED irradiation (Scheme 1C). A series of mechanistic investigations identified that the process involves a triplet-sensitization of the xanthates by the long-lived triplet state of the iridium-based photocatalyst that triggers the radical chain process [27].

\section{Results and Discussion}

Over the last decade, there has been a remarkable advance in synthetic chemistry that takes advantage of various chromophores (either metallic or organic) having visible-light charge transfer absorption [28-37]. In the area of polymer synthesis, visible-light-induced RAFT polymerization of xanthates with vinyl monomers under blue LED (light-emitting diode) irradiation has been reported [38-41]. Visible-light-induced single unit monomer insertion of the thiocarbonylthio compounds has also been developed for the synthesis of the sequence-controlled oligomers [41-45]. For example, the group of Boyer and $\mathrm{Xu}$ developed $f a c$ - $\operatorname{Ir}(\mathrm{ppy})_{3}$ (6)-catalyzed polymerization of xanthate 4 with various vinyl monomers such as vinyl acetate, providing polymers of type $\mathbf{5}$ having a high molecular weight with a narrow molecular weight distribution. It was proposed that the polymerization is initiated by single-electron reduction of xanthate 4 by the highly reducing photo-excited state of $f a c-\operatorname{Ir}(\mathrm{ppy})_{3}$ (6) [46], although the details were not elucidated (Scheme 2) [39,40].

Based on these backgrounds, we wondered if the degenerative transfer of xanthates onto olefins could be facilitated by visiblelight photocatalysis under milder reaction conditions. We therefore commenced our investigation with the reaction of ethyl ethoxycarbonylmethyl xanthate (1a) and 1-octene (2a) using $f a c-\operatorname{Ir}(\mathrm{ppy})_{3}(\mathbf{6})$ in DMSO under blue LED irradiation $\left(\lambda_{\max }=\right.$ $469 \mathrm{~nm}$, Table 1, entry 1). As expected, the desired xanthate transfer was observed, while the process efficiency was not very high, forming 3 aa in only $58 \%$ yield with incomplete conversion even after stirring for $20 \mathrm{~h}$. Interestingly, we found that the employment of the less reducing Ir catalysts 7 [46] and 8 [47] also worked for the process (Table 1, entries 2 and 3). Espe-

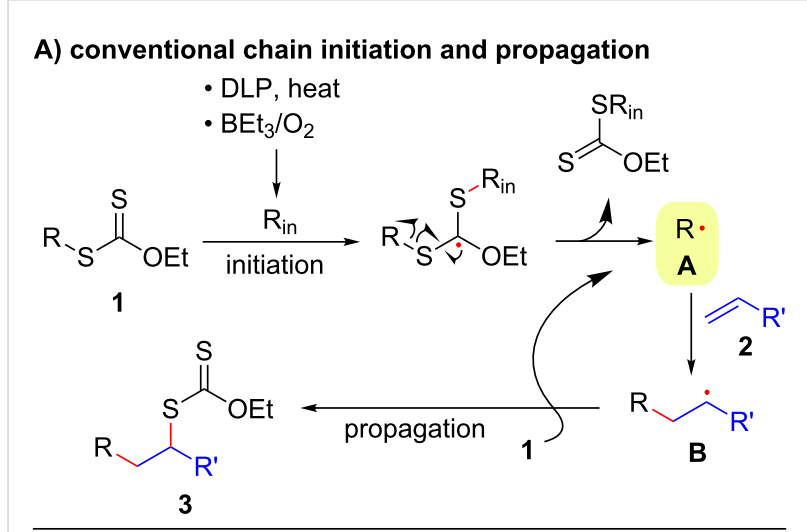

B) use of S-Bz xanthate under visible light by Zard

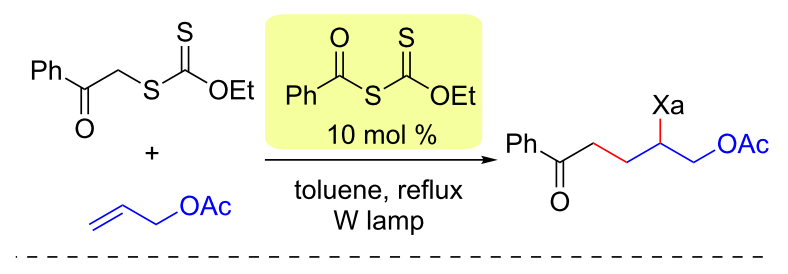

- visible-light induced fragmentation of S-Bz xanthate

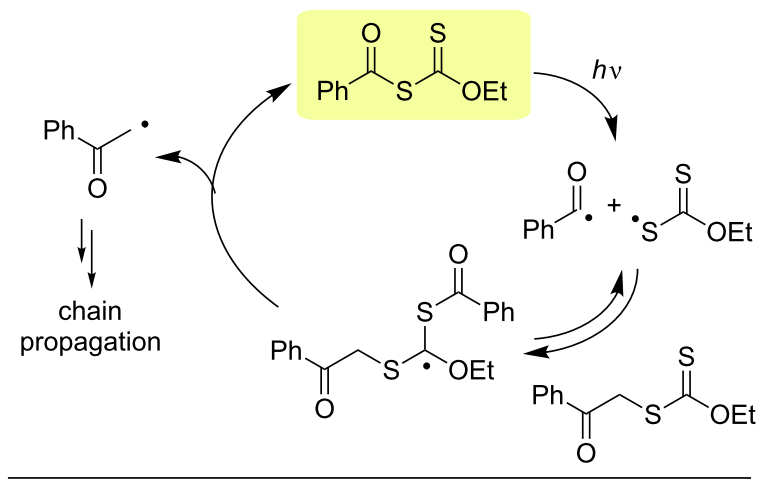

C) this work

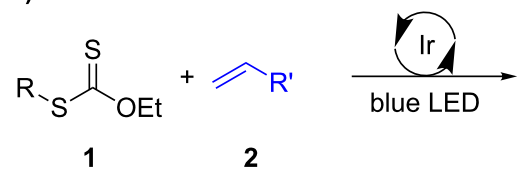<smiles>[R]CC([R])SC(=S)OCC</smiles>

- $0.5-1 \mathrm{~mol} \%$ of iridium photocatalyst

- milder reaction condition $\left(<30^{\circ} \mathrm{C}\right)$

- radical chain triggered by triplet-triplet sensitization

Scheme 1: Degenerative radical transfer of xanthates to olefins.

cially, the rather oxidizing $\left[\operatorname{Ir}\left\{\mathrm{dF}\left(\mathrm{CF}_{3}\right) \text { ppy }\right\}_{2}(\mathrm{dtbpy})\right]\left(\mathrm{PF}_{6}\right)(\mathbf{8})$ resulted in full conversion of $\mathbf{1 a}$, affording $\mathbf{3 a a}$ in $89 \%$ yield (Table 1, entry 3). Other photocatalysts, such as $\mathrm{Ru}(\mathrm{bpy})_{3} \mathrm{Cl}_{2}$ (9) [46], fluorescein (10) [48], and phenoxazine 11 [49], were not optimal for the present transformation (Table 1, entries 4-6). It should be noted that the reaction without the photocatalyst under visible light- and halogen lamp irradiation resulted in poorer conversion with formation of $\mathbf{3 a a}$ in only $10 \%$ and $30 \%$ yield, respectively, suggesting that the photocatalyst was important for the degenerative transfer of xanthate 1a (Table 1, 


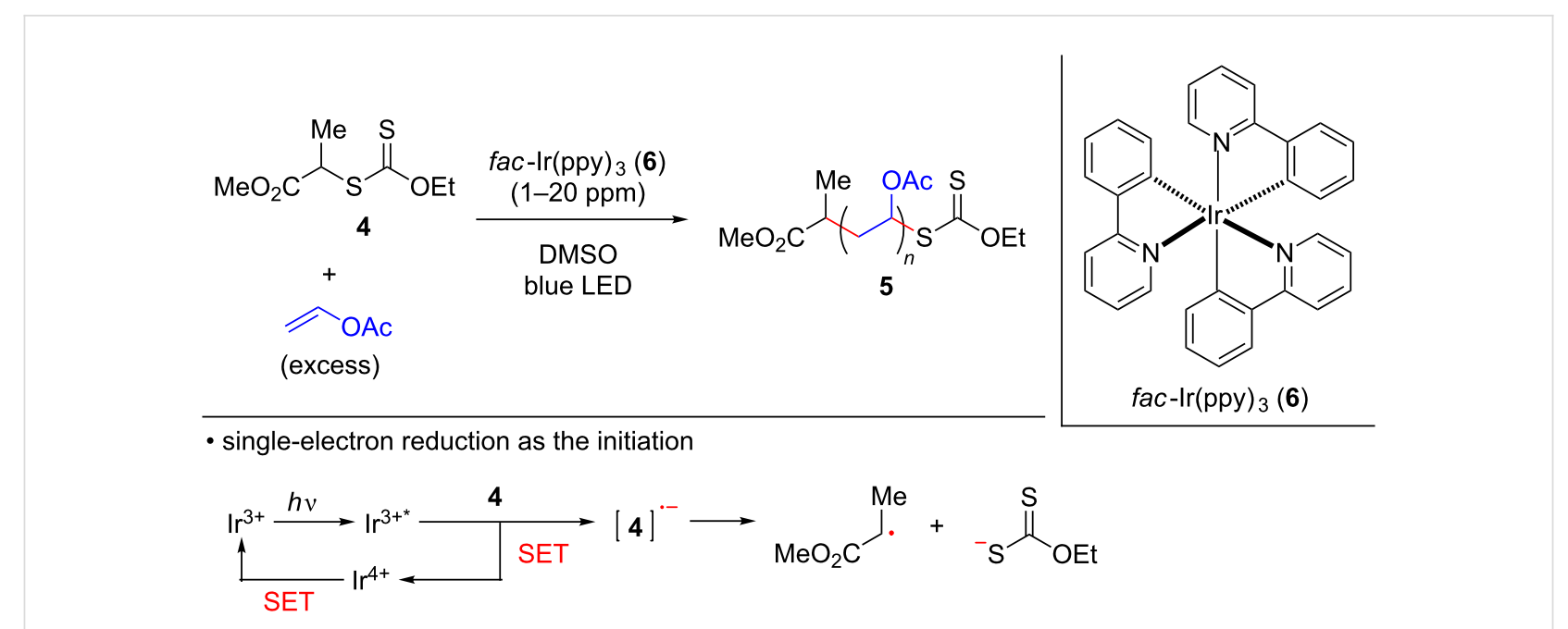

Scheme 2: Photocatalytic RAFT polymerization of xanthate 4

entries 7 and 8). On the other hand, the employment of a $365 \mathrm{~nm}$ UV lamp in place of the blue LED gave 3aa in $75 \%$ yield, although a slower reaction rate was observed compared to the optimal reaction conditions (Table 1, entry 9).

In principle, visible-light-mediated photocatalysis can serve for electron transfer (for either oxidation or reduction) and/or for energy transfer. We found that the reduction potential $E_{\mathrm{p} / 2}$ of xanthate $1 \mathrm{a}$ is $-1.78 \mathrm{~V}$ vs SCE, which is not sufficient to be reduced by the photoexcited states of Ir catalysts $6-8\left(E_{1 / 2}\right.$ of $6^{*}, 7^{*}$ and $\mathbf{8}^{*}=-1.73,-1.28$, and $-0.89 \mathrm{~V}$ vs SCE, respectively $[46,47])$. Apparently, photoinduced single-electron reduction of xanthate 1a by the photoexcited state of the optimal catalyst $\mathbf{8}$ is not feasible. In contrast, the triplet energy $E_{\mathrm{T}}$ of xanthate 1a was estimated as $57.5 \mathrm{kcal} / \mathrm{mol}$ by DFT calculation, that is close to those of photocatalysts 7 and $8\left(E_{\mathrm{T}}=60.1 \mathrm{kcal} / \mathrm{mol}\right.$ [50]), indicating that the process could be initiated by the triplet sensitization pathway [51,52]. This assumption is in agreement with the lower process efficiency (Table 1, entry 1) observed in the reaction with $f a c-\operatorname{Ir}(\mathrm{ppy})_{3}(\mathbf{6})$ that possesses a lower triplet energy $\left(E_{\mathrm{T}}=55.2 \mathrm{kcal} / \mathrm{mol}[50]\right)$. The optimal photocatalyst 8 [47] has a longer excited state lifetime than 7 does [46], suggesting that the lifetime of the excited state of the photocatalyst is a key factor for the energy transfer mechanism.

To obtain a detailed mechanistic insight, steady-state photoluminescence (PL) quenching of photocatalyst 8 was examined using xanthate 1a and 1-octene (2a) as potential quenchers (Figure 1). The intensity of the PL peak of photocatalyst 8 (concentration of $\mathbf{8}$ was fixed as $25 \mu \mathrm{M}$ solution in degassed DMSO for all the samples; for details see Supporting Information File 1) at $480 \mathrm{~nm}$, arising from the radiative emission of the ${ }^{3}$ MLCT state of the photocatalyst, was measured using $410 \mathrm{~nm}$ light excitation. When the concentration of xanthate 1a was gradually increased, a reduction in the PL intensity $(I)$ of photocatalyst 8 was observed (Figure 1A). The Stern-Volmer plot of the ratio $I_{0} / I$, where $I_{0}$ is the initial PL intensity in the absence of quencher, versus concentration of 1 a showed a linear relationship with a quenching rate $k_{\mathrm{q}}=1.25 \times 10^{7} \mathrm{M}^{-1} \mathrm{~s}^{-1}$ (see Supporting Information File 1). On the other hand, the addition of 1-octene $(\mathbf{2 a}, 40 \mathrm{mM})$, in place of xanthate $\mathbf{1 a}$, resulted in only a small PL quenching of photocatalyst 8 ( $<8 \%$, Figure 1B).

The time-resolved PL lifetime decay profiles of photocatalyst 8 ( $25 \mu \mathrm{M}$ solution in degassed DMSO, $410 \mathrm{~nm}$ pulse excitation and monitoring emission at $480 \mathrm{~nm}$ ) were recorded in the absence of a quencher, and in the presence of xanthate 1a and 1-octene (2a, $40 \mathrm{mM}$, Figure 1C). The lifetime profiles were described using a mono-exponential decay function with a lifetime of $1.40 \mu \mathrm{s}$ in the absence of a quencher, and 1.03 and $1.37 \mu$ s in the presence of xanthate 1a and 1-octene (2a), respectively. The decrease in the PL lifetime of photocatalyst 8 in the presence of xanthate 1a suggests that they are interacting with each other. On the other hand, only a very weak interaction exists between 1-octene (2a) and the photocatalyst $\mathbf{8}$ as demonstrated by the insignificant PL quenching of the photocatalyst [53].

The ns-transient absorption (TA) spectra of photocatalyst 8 ( $25 \mu \mathrm{M}$ solution in degassed DMSO) obtained using $355 \mathrm{~nm}$ pulse excitation and recorded at different delay times are shown in Figure 2A. The band between $450 \mathrm{~nm}$ and $600 \mathrm{~nm}$ is attributed to the excited ${ }^{3}$ MLCT state of the photocatalyst [53-55]. The positive $\triangle \mathrm{OD}$ feature in the UV region $(<400 \mathrm{~nm})$ is also ascribed to the excited ${ }^{3} \mathrm{MLCT}$ state [55]. The transient kinetic profile probed at $480 \mathrm{~nm}$ decays mono-exponentially with a 
Table 1: Optimization of reaction conditions. ${ }^{a}$

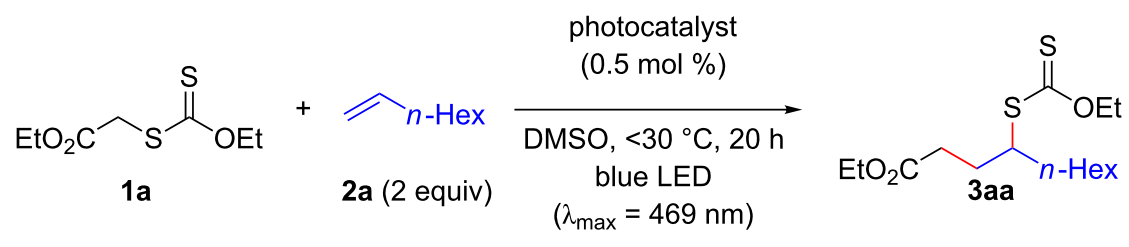

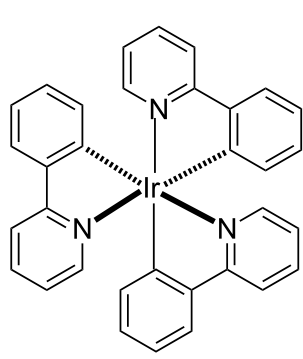

fac-Ir(ppy) ${ }_{3}(6)$

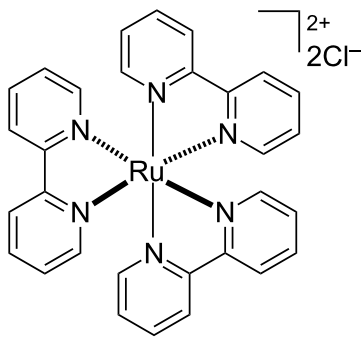

$\mathrm{Ru}(\mathrm{bpy})_{3} \mathrm{Cl}_{2}$ (9)

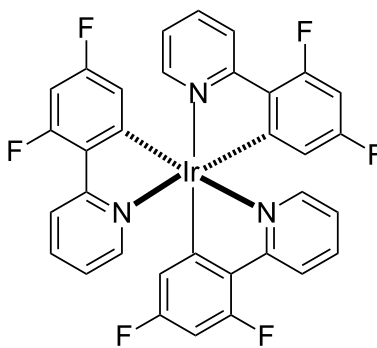

$\operatorname{Ir}(\mathrm{Fppy})_{3}(7)$

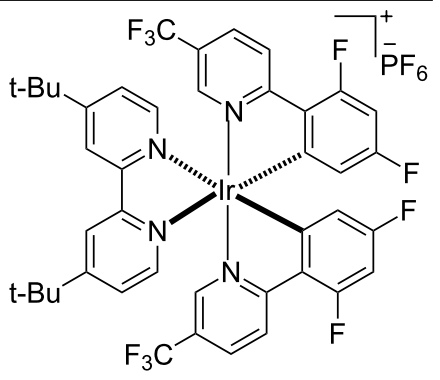

$\left[\operatorname{Ir}\left\{\mathrm{dF}\left(\mathrm{CF}_{3}\right) \mathrm{ppy}\right\}_{2}(\mathrm{dtbbpy})\right]\left(\mathrm{PF}_{6}\right)(\mathbf{8})$<smiles>O=C(O)c1ccccc1-c1c2ccc(=O)cc-2oc2cc(O)ccc12</smiles><smiles>[Al]c1ccc2c(c1)Oc1cc([Al]c3ccc(-c4ccccc4)cc3)ccc1N2c1cccc2ccccc12</smiles>

11

fluorescein (10)

\begin{tabular}{|c|c|c|c|c|c|}
\hline Entry & Photocat. & $\begin{array}{l}\left.E_{1 / 2\left(\mathrm{M}+/ \mathrm{M}^{*}\right)}\right) \\
{[\mathrm{V} \text { vs SCE }]^{\mathrm{b}}}\end{array}$ & $\begin{array}{c}E_{\mathrm{T}} \\
{[\mathrm{kcal} / \mathrm{mol}]^{\mathrm{b}}}\end{array}$ & $\begin{array}{l}\text { Conv. } \\
{[\%]^{c}}\end{array}$ & $\begin{array}{l}\text { Yield } \\
{[\%]^{c}}\end{array}$ \\
\hline 1 & 6 & -1.73 & 55.2 & 64 & 58 \\
\hline 2 & 7 & -1.28 & 60.1 & 38 & 34 \\
\hline 3 & 8 & -0.89 & 60.1 & $>99$ & $90(89)^{d}$ \\
\hline 4 & 9 & -0.81 & 46.5 & 13 & 13 \\
\hline 5 & 10 & -1.42 & 44.7 & 34 & 31 \\
\hline 6 & 11 & -1.80 & 56.5 & 9 & 9 \\
\hline 7 & none & - & - & 10 & 10 \\
\hline $8^{e, f}$ & none & - & - & 39 & 30 \\
\hline 99 & none & - & - & 84 & 75 \\
\hline
\end{tabular}

aThe reactions were conducted using $0.3-0.5 \mathrm{mmol}$ of xanthate $1 \mathrm{a}, 1$-octene $\left(2 \mathrm{a}, 2\right.$ equiv) and a photocatalyst in $\mathrm{DMSO}(1 \mathrm{M})$ at $<30{ }^{\circ} \mathrm{C}$ with irradiation of a blue LED strip $\left(\lambda_{\max }=469 \mathrm{~nm}, 15 \mathrm{~W} / \mathrm{m}, 1.5 \mathrm{~m}\right)$ under an argon atmosphere. ${ }^{\mathrm{b}}$ The values were obtained from references [46-50]. ${ }^{\mathrm{C}} \mathrm{NMR}$

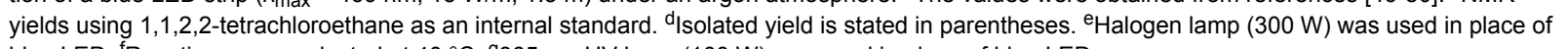
blue LED. f Reaction was conducted at $40{ }^{\circ} \mathrm{C}$. $9365 \mathrm{~nm}$ UV lamp $(100 \mathrm{~W})$ was used in place of blue LED.

lifetime of $1.73 \mu$ s (Figure $2 \mathrm{~B}$ ); close to the lifetime of the excited ${ }^{3}$ MLCT state of photocatalyst 8 measured in Figure 1C. The ns-TA spectra of xanthate $\mathbf{1 a}$ in degassed DMSO, measured using $355 \mathrm{~nm}$ pulse excitation, at various delay times show a broad band centered at $\approx 620 \mathrm{~nm}$ (Figure $2 \mathrm{C}$ ). This band has previously been ascribed to the absorption of the xanthic acid radical formed plausibly from homolytic $\mathrm{C}-\mathrm{S}$ bond cleavage of the short-lived triplet state of xanthate 1a [22].
The ns-TA spectra of photocatalyst $8(25 \mu \mathrm{M})$ in the presence of xanthate $1 \mathbf{a}(40 \mathrm{mM})$ in degassed DMSO at various delay times are shown in Figure 2D. The kinetic profile at $480 \mathrm{~nm}$ is described using a mono-exponential decay function with a quenched lifetime of $1.27 \mu \mathrm{s}$. The ca. $37 \%$ decrease in the lifetime of the excited ${ }^{3}$ MLCT state of photocatalyst 8 observed in the PL lifetime decay measurement (Figure 1C) and ns-TA kinetic measurement (Figure 2B) can be rationalized using 

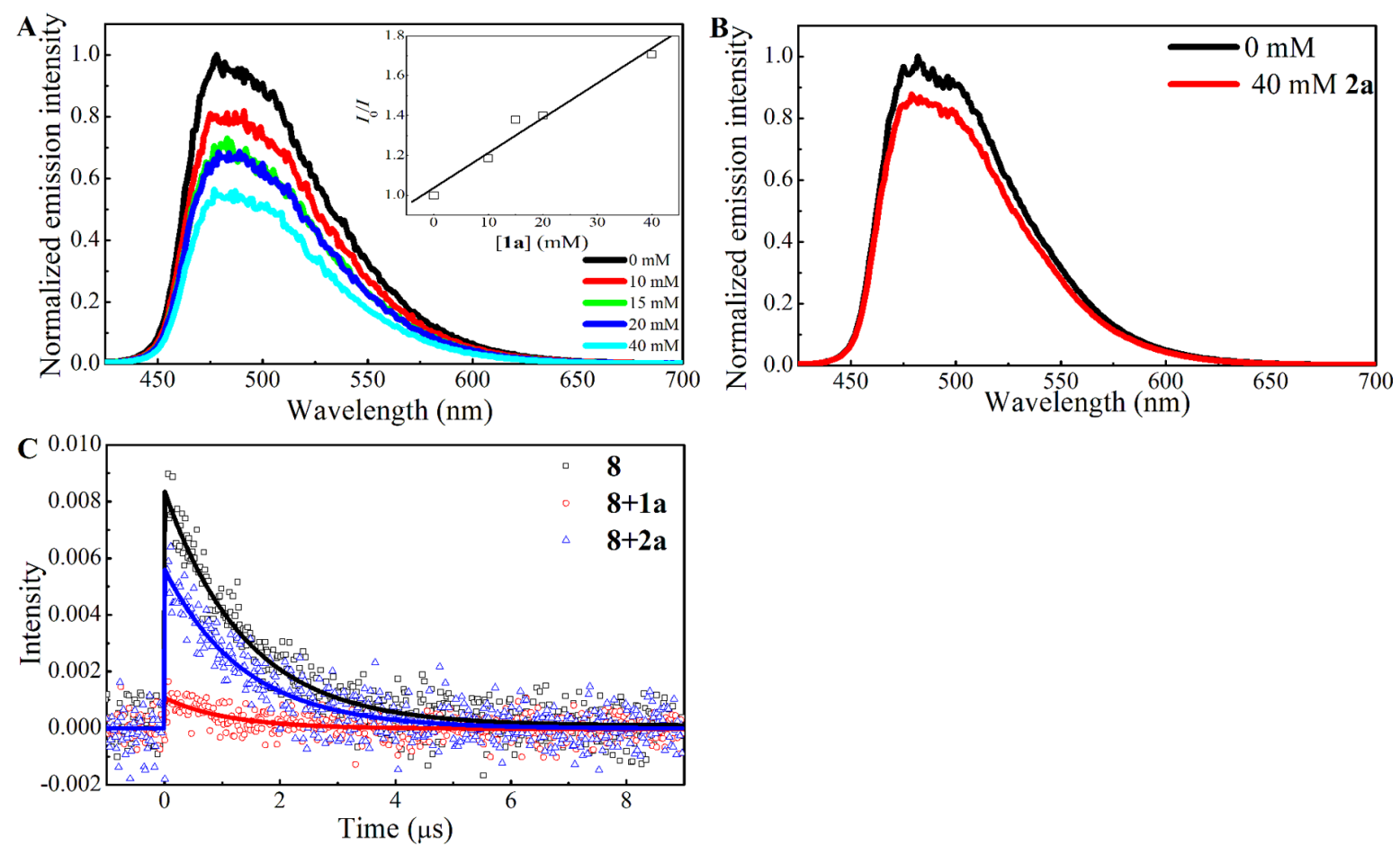

Figure 1: Photoluminescence $(P L)$ spectra of the ${ }^{3} M L C T$ state of 8 in degassed DMSO solvent with $(A)$ various concentrations of xanthate 1a added and (B) $40 \mathrm{mM}$ of 1-octene (2a) added. The inset of (A) gives the Stern-Volmer plot of the corrected PL quenching at $480 \mathrm{~nm}$. (C) Time-resolved PL lifetime decay profiles of photocatalyst $\mathbf{8}$ in degassed DMSO in the absence of quencher (square), presence of xanthate $1 \mathrm{a}$ (circle) and presence of 1-octene (2a, triangle). The mono-exponential decay fits are provided.
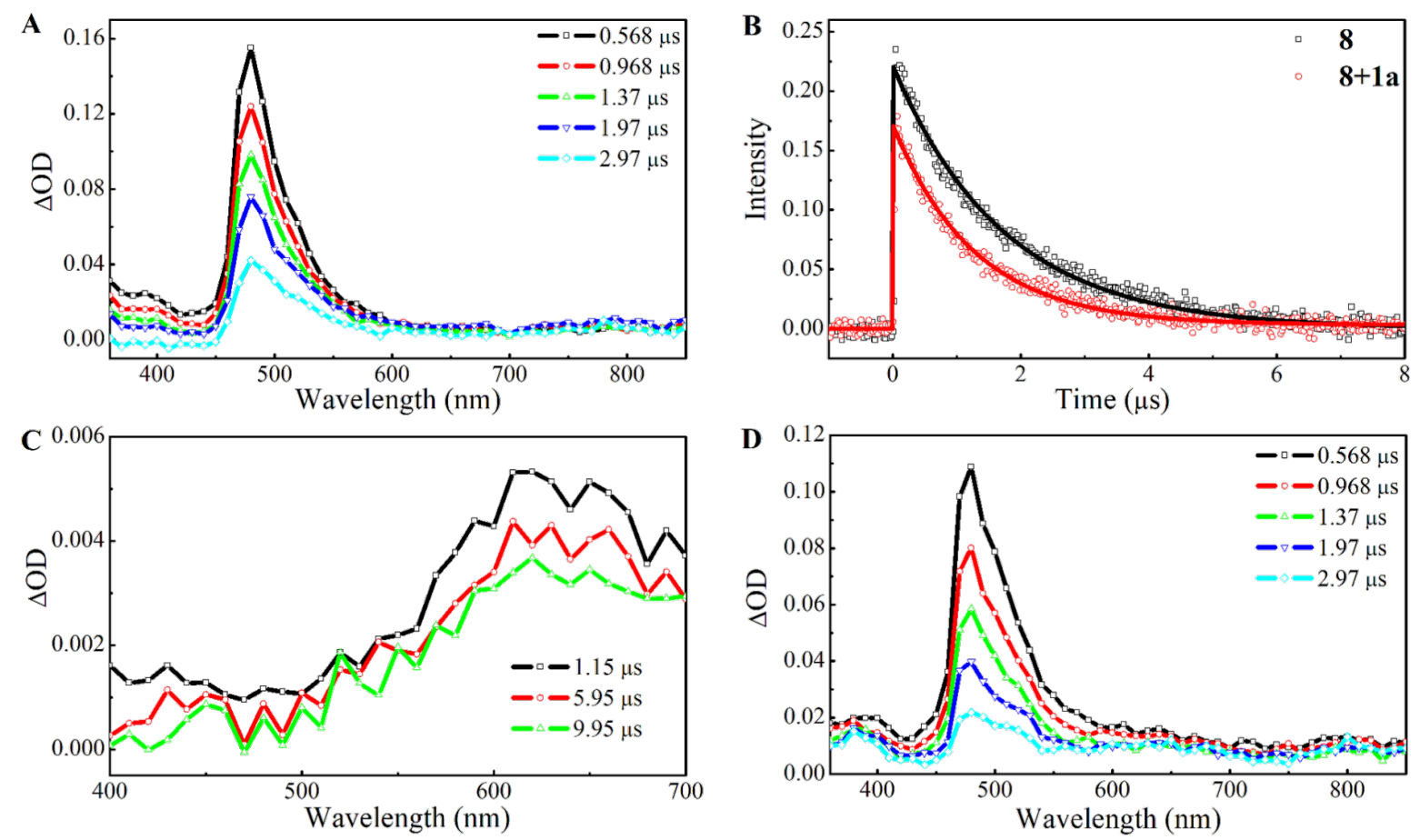

Figure 2: (A) ns-Transient absorption spectra of photocatalyst 8 in degassed DMSO recorded at different delay times (excitation wavelength = $355 \mathrm{~nm}$ ). (B) ns-TA kinetic profile probed at $480 \mathrm{~nm}$ for photocatalyst 8 in the absence and presence of xanthate 1a. (C) and (D) ns-Transient absorption spectra of xanthate $1 \mathrm{a}$ and $\mathbf{8}$ in the presence of $\mathbf{1 a}$ in degassed DMSO recorded at different delay times, respectively (excitation wavelength = $355 \mathrm{~nm})$. 
either an energy-transfer or an electron-transfer mechanism. For the same delay times and in the presence of $\mathbf{1 a}$, the $\Delta \mathrm{OD}$ values in Figure 2D are smaller than those of photocatalyst $\mathbf{8}$ in the absence of the xanthate (Figure 2A). This is due to the quenching of the ${ }^{3}$ MLCT state of the photocatalyst. If an electron-transfer process occurs from photocatalyst $\mathbf{8}$ to xanthate 1a, the $\triangle O D$ values in the UV region should be noticeably higher due to the TA band contribution from $\mathrm{bpy}^{-}$connected to an Ir metal center of the +4 oxidation state (i.e., absorption due to $\left.\left[\mathrm{Ir}^{\mathrm{IV}}\left\{\mathrm{dF}\left(\mathrm{CF}_{3}\right) \text { ppy }\right\}_{2}\right]\left(\mathrm{dtbpy}^{-}\right)\right]$species $)$[55]. However, this was not observed in Figure 2D; suggesting that quenching is due to energy transfer rather than electron transfer, and in agreement with the thermodynamic consideration where singleelectron reduction of xanthate 1a likely does not proceed with the excited photocatalyst $\mathbf{8}$. We therefore propose that the observed PL quenching is due to energy transfer from the excited ${ }^{3}$ MLCT state of photocatalyst 8 to the triplet state of xanthate 1a. When comparing the normalized TA spectra of photocatalyst 8 in the absence and presence of xanthate 1a (see Supporting Information File 1, Figure S4), an additional contribution from a broad $\triangle O D$ band that stretches from $500 \mathrm{~nm}$ to $800 \mathrm{~nm}$ is seen for the latter which is attributed to the absorption of the xanthic acid radical. In this case, the xanthic acid radical is formed from the homolytic bond cleavage of the excited triplet state of 1 a formed by direct $355 \mathrm{~nm}$ laser light excitation and triplet-triplet energy transfer involving the excited photocatalyst 8.

To confirm the possibility of a direct photoexcitation of xanthate 1 using blue LED light irradiation as an alternative mechanism, a steady-state UV-vis absorption spectroscopy study of xanthate 1a was conducted (Figure 3). The UV-vis absorption spectrum of $\mathbf{1 a}$ ( $1 \mathrm{mM}$ in DMSO) showed absorption bands at 340-390 $\mathrm{nm}$ assigned to the $\mathrm{n} \rightarrow \pi^{*}$ electronic transition of the $\mathrm{C}=\mathrm{S}$ bond as a characteristic peak of thiocarbonyl containing compounds [56]. In fact, the reaction of $\mathbf{1 a}$ and $\mathbf{2 a}$ under $365 \mathrm{~nm}$ UV lamp irradiation without a photocatalyst delivered product $3 \mathbf{a a}$ in $75 \%$ yield (Table 1, entry 9). This indicates the excitation of xanthate 1a through an $n \rightarrow \pi^{*}$ electronic transition of the $\mathrm{C}=\mathrm{S}$ bond is in operation in the UV irradiation process.

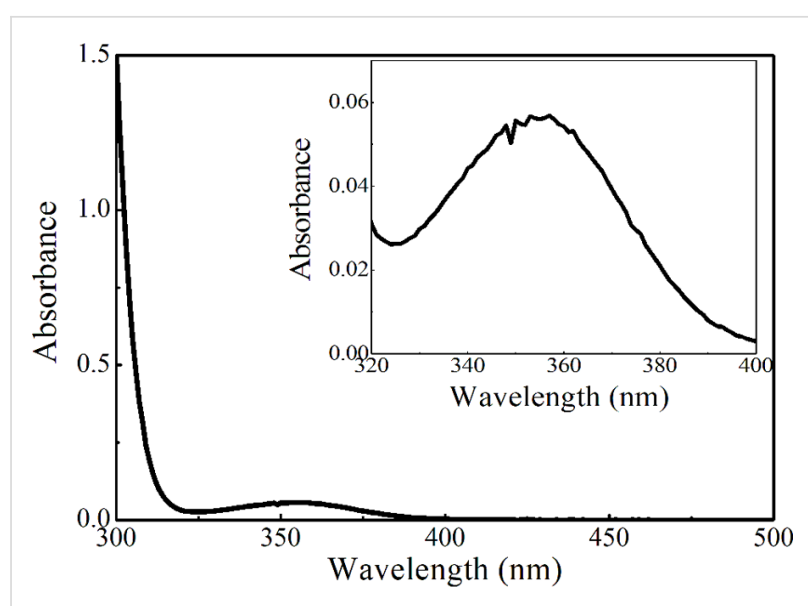

Figure 3: UV-vis absorption spectrum of $1 \mathrm{a}$ (1 $\mathrm{mM}$ solution in DMSO).

The involvement of a radical chain mechanism was further confirmed by calculating the quantum yield $(\Phi)$ because a chain process provides multiple equivalents of product per photon absorbed by the photocatalyst $(\Phi>1)$. The photon flux of blue LED $\left(\lambda_{\max }=469 \mathrm{~nm}\right)$ was determined using the potassium ferrioxalate actinometer [57,58]. After irradiation of the mixture of xanthate $\mathbf{1 a}$ and olefin $\mathbf{2 b}$ under optimal reaction conditions with blue LED light irradiation for $4 \mathrm{~h}$ (Scheme 3), product $3 \mathbf{a b}$ was obtained in $58 \%$ yield. This is consistent with 12 equivalents of xanthate adduct 3ab produced per photon absorbed by the photocatalyst $\mathbf{8}(\Phi=12)$.

On the basis of these observations, a proposed triplet sensitization mechanism is illustrated in Scheme 4. In this reaction, photocatalyst 8 serves as a catalyst of an initiation step through energy transfer from photoexcited $8 *$ to xanthate $\mathbf{1}$ to form excited xanthate $1^{*}$ and regeneration of 8 in the ground state [59-61]. The resulting excited xanthate $1 *$ induces homolytic scission of the $\mathrm{C}-\mathrm{S}$ bond to generate the stabilized S-radical and $\mathrm{C}$-radical $\mathbf{A}$, which then enters the innate radical chain-propagation mechanism to provide xanthate adduct $\mathbf{3}$. It is worth noting that at the wavelength of the light source used (469 nm), xanthate 1a absorbs a negligible amount of light (Figure 3) and the majority of triplet $\mathbf{1 a}$ formed is due to energy transfer from excited catalyst $\mathbf{8}^{*}$.

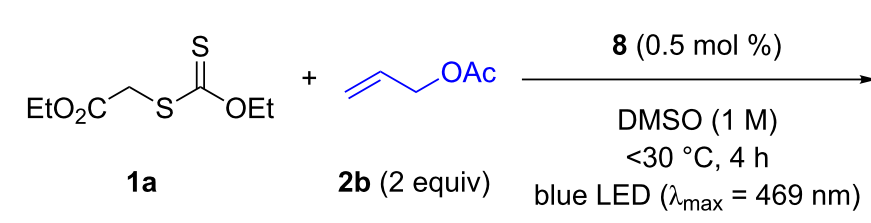

Scheme 3: Determination of quantum yield. 


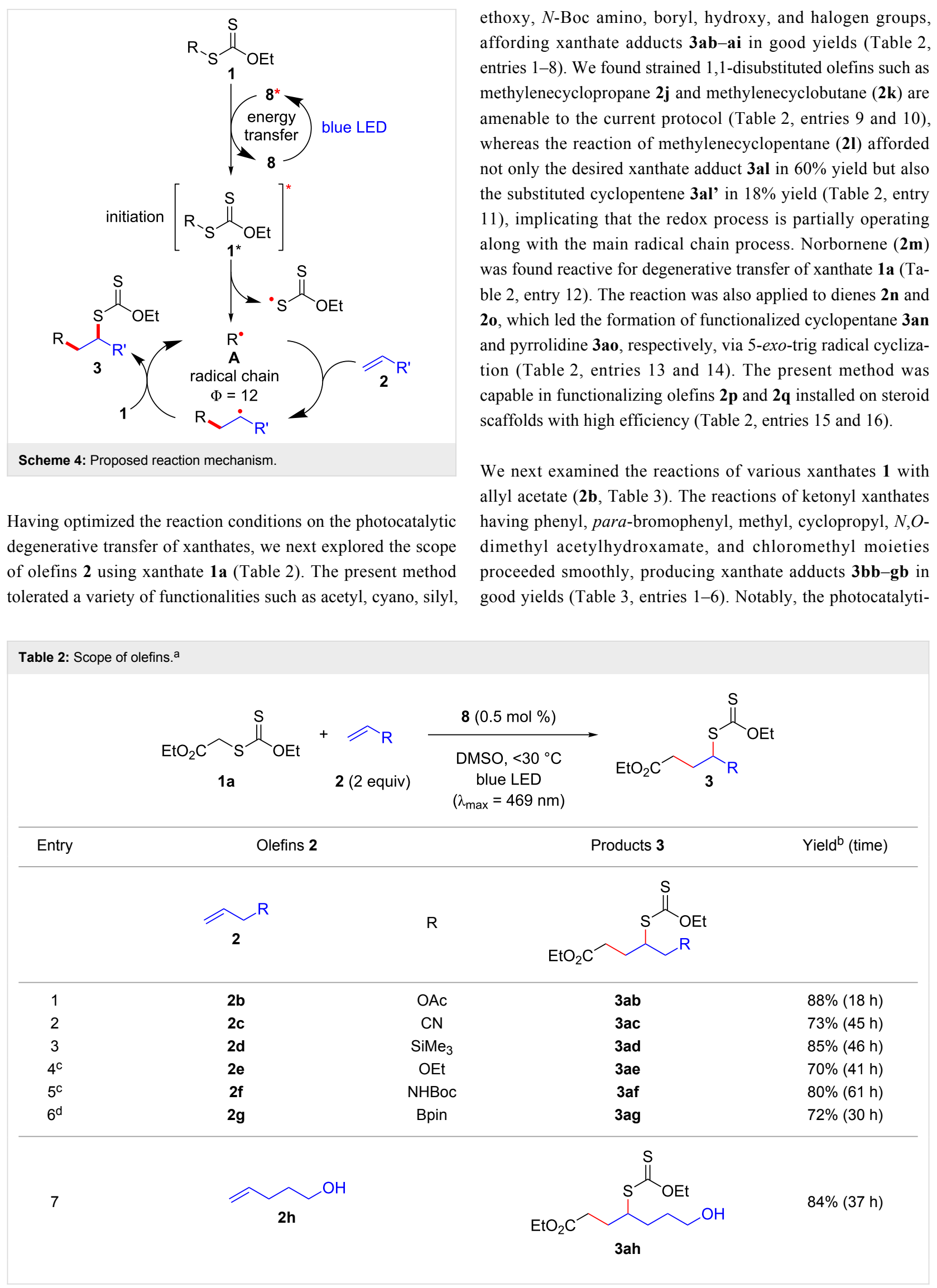


Table 2: Scope of olefins. ${ }^{\text {a }}$ (continued)

8

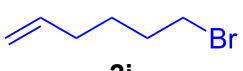

$2 \mathbf{i}$<smiles>C=C1C(C(C)=O)C1C(=O)OC</smiles>

2j

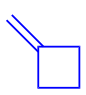

10

2k

$11^{d}$

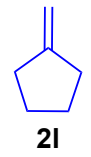

12

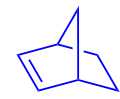

$2 \mathrm{~m}$<smiles>CCOC(=O)CCC(CCCCBr)SC(=S)OCC</smiles>

3ai<smiles>CCOC(=O)CCC1(SC(=S)OCC)C(C(C)=O)C1C(=O)OC</smiles>

3aj

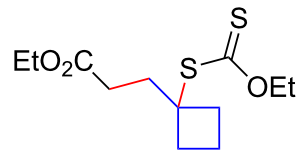

3ak

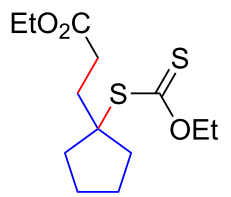

3al

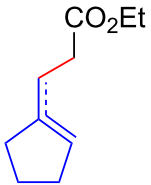

3al'

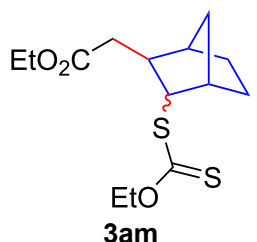

$73 \%(10 \mathrm{~h})$

$(\mathrm{dr}=78: 22)$

$18 \%^{\mathrm{e}}(20 \mathrm{~h})$ endo/exo $=80: 20$
13<smiles>C=CCC1(CC=C)CC1C</smiles>
$\mathrm{EtO}_{2} \mathrm{C} \mathrm{CO} \mathrm{CO}_{2} \mathrm{Et}$

2n

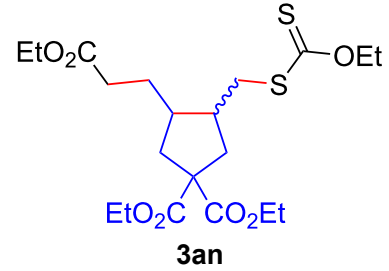

3an

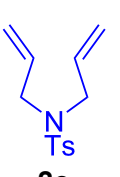

20

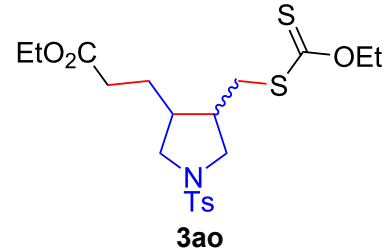

$74 \%(13 \mathrm{~h})$ $(\mathrm{dr}=71: 29)$ 
Table 2: Scope of olefins. ${ }^{\text {a }}$ (continued)

$15^{\mathrm{f}}$<smiles>C=CCCC(=O)OC1CCC2(C)CC3(C)CCC4C(CCC5(C)C(=O)CCC45)C3CC2C1</smiles><smiles>CCOC(=O)CCCC(CCC(=O)OC1CCC2(C)C3CCC4(C)C(=O)CCC4C3CCC2(C)C1)SC(=S)OCC</smiles>

3ap
$94 \%(26 \mathrm{~h})$ $(d r=50: 50)$

$16^{9}$

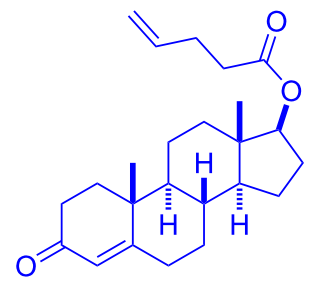

$2 q$<smiles>CCOC(=O)CCC(CCC(=O)O[C@H]1CC[C@H]2[C@@H]3CCC4=CC(=O)CC[C@]4(C)[C@H]3[C@@H]1CCC2(C)C)SC(=S)OCC</smiles>

$3 a q$

${ }^{\text {a }}$ The reactions were conducted using xanthate $1 \mathrm{a}(0.3-0.5 \mathrm{mmol})$, olefin 2 (2 equiv) and $8(0.5 \mathrm{~mol} \%)$ in DMSO $(1 \mathrm{M})$ at $<30{ }^{\circ} \mathrm{C}$ with irradiation of a blue LED strip $\left(\lambda_{\max }=469 \mathrm{~nm}\right)$ under an argon atmosphere. b Isolated yields are stated. ${ }^{c} 1 \mathrm{~mol} \%$ of 8 was used. ${ }^{\mathrm{d}} 4$ equiv of olefin 2 were used. eNMR yield using 1,1,2,2-tetrachloroethane as an internal standard. ${ }^{\mathrm{f}}$ The reaction was conducted in DMSO/DCE 1:1 (0.5 M). ${ }^{\mathrm{g}}$ The reaction was conducted in DMSO/DCE 3:5 (0.4 M).

Table 3: Scope of xanthates. ${ }^{a}$<smiles>[R]SC(=S)OCCOC(=O)O</smiles>

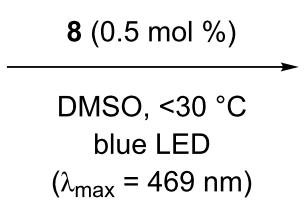<smiles>[R]CC(COC(C)=O)SC(=S)OCC</smiles>

1<smiles>CCOC(=S)SCC(=O)c1ccccc1</smiles>

1b

$\mathrm{Br}$

2<smiles>CCOC(=S)SCC(=O)c1ccc(Br)cc1</smiles>

3<smiles>CCOC(=S)SCC(=O)C1CC1</smiles>

1d<smiles>CCOC(=O)SC(CCC(=O)c1ccccc1)COC(C)=S</smiles>

$3 b b$<smiles>CCOC(=S)SC(CCC(=O)c1ccc(Br)cc1)COC(C)=O</smiles>

$3 \mathrm{cb}$<smiles>CCOC(=S)SC(CCC(=O)C1CC1)COC(C)=O</smiles>

$3 \mathrm{db}$ $69 \%(47 \mathrm{~h})$

$78 \%(44 \mathrm{~h})$ 
Table 3: Scope of xanthates. ${ }^{\text {a }}$ (continued)

$4^{c}$<smiles>CCOC(=S)SCC(C)=O</smiles>

$1 e$

5<smiles>CCOC(=S)SCC(=O)N(C)OC</smiles>

6<smiles>CCOC(=S)SCC(=O)CCl</smiles>

$1 \mathrm{~g}$

$7^{\mathrm{d}}$<smiles>CCOC(=S)SCC(=O)CSC(=S)OCC</smiles>

1h

8<smiles>CCOC(=S)SCN1C(=O)c2ccccc2C1=O</smiles>

9<smiles>CCOC(=S)SCN1C(=O)CCC1=O</smiles>

10<smiles>CCOC(=O)SC(CCC(C)=O)COC(C)=O</smiles>

$3 e b$<smiles>CCOC(=O)SC(CCC(=O)N(C)OC)COC(C)=O</smiles>

$3 \mathrm{fb}$<smiles>CCOC(=S)SC(CCC(=O)CCl)COC(C)=O</smiles>

$3 g b$<smiles>CCOC(=S)SC(CCC(=O)CCC(COC(C)=O)SC(=S)OCC)COC(C)=O</smiles><smiles>CCOC(=S)SC(CCN1C(=O)c2ccccc2C1=O)COC(C)=O</smiles>

3ib<smiles>CCOC(=S)SC(CCN1C(=O)CCC1=O)COC(C)=O</smiles>

3jb<smiles>CCOC(=S)SC(COC(C)=O)CC([AsH3])C(F)(F)F</smiles>

$82 \%(71 \mathrm{~h})$

$81 \%(27 h)$

$75 \%(17 \mathrm{~h})$

$69 \%(52 \mathrm{~h})$

$(d r=52: 48)$

$80 \%(41 \mathrm{~h})$

$56 \%(24 \mathrm{~h})$

$74 \%(24 \mathrm{~h})$

(dr = 63:37)

aThe reactions were conducted using xanthate $1(0.3 \mathrm{mmol})$, olefin $\mathbf{2 b}\left(2\right.$ equiv) and $8(0.5 \mathrm{~mol} \%)$ in DMSO $(1 \mathrm{M})$ at $\angle 30{ }^{\circ} \mathrm{C}$ with irradiation of a blue LED strip $\left(\lambda_{\max }=469 \mathrm{~nm}\right)$ under an argon atmosphere. ${ }^{b}$ Isolated yields are stated. ${ }^{c} 1 \mathrm{~mol} \%$ of 8 was used. ${ }^{d}$ Five equivalents of olefin $\mathbf{2 b}$ were used.

cally cleavable aryl bromide (Table 3 , entry 2 ) and the $\alpha$-chlorocarbonyl moiety (Table 3 , entry 6 ) were also stable under the current reaction conditions $[62,63]$. Furthermore, double addition of bisxanthate $\mathbf{1 h}$ was successfully achieved in the presence of 5 equiv of olefin $\mathbf{2 b}$, giving $\mathbf{3 h b}$ in $69 \%$ yield (Table 3 , entry 7). This method is also suitable for generating $\alpha$-aminoalkyl radicals from phthalimidomethyl and succinimidomethyl xanthates [64], as well as $\alpha$-trifluoromethylamino xanthate $\mathbf{1 k}$ [65] to afford desired products $\mathbf{3 i b}-\mathbf{k b}$ in good to moderate yields (Table 3, entries 8-10).

\section{Conclusion}

We have established a protocol for a photoinduced radical addition of xanthates to olefins using an iridium-based photocata- 
lyst under blue LED irradiation, leading to diverse xanthate adducts. This reaction proceeds through a radical-chain propagation mechanism via an initiation involving a triplet-sensitization process of xanthates by an excited iridium-based photocatalyst.

\section{Supporting Information}

\section{Supporting Information File 1}

Full experimental details and analytical data.

[https://www.beilstein-journals.org/bjoc/content/

supplementary/1860-5397-14-283-S1.pdf]

\section{Acknowledgements}

This work was supported by funding from Nanyang Technological University and the Singapore Ministry of Education (Academic Research Fund Tier 1: RG2/15 and RG2/18 for S.C. and Academic Research Fund Tier 1: RG115/16 for E.K.L.Y.).

\section{ORCID ${ }^{\circledR}$ iDs}

Atsushi Kaga - https://orcid.org/0000-0001-5439-6627 Joel Yi Jie Lim - https://orcid.org/0000-0001-7179-2613 Yunpeng Lu - https://orcid.org/0000-0003-2493-7853 Shunsuke Chiba - https://orcid.org/0000-0003-2039-023X

\section{References}

1. Zard, S. Z. Acc. Chem. Res. 2018, 51, 1722-1733. doi:10.1021/acs.accounts.8b00201

2. Quiclet-Sire, B.; Zard, S. Z. Synlett 2017, 28, 2685-2696. doi:10.1055/s-0036-1590809

3. Quiclet-Sire, B.; Zard, S. Z. Isr. J. Chem. 2017, 57, 202-217. doi:10.1002/ijch.201600094

4. Zard, S. Z. Org. Biomol. Chem. 2016, 14, 6891-6912. doi:10.1039/c6ob01087c

5. Quiclet-Sire, B.; Zard, S. Z. Synlett 2016, 27, 680-701. doi:10.1055/s-0035-1561300

6. Debien, L.; Quiclet-Sire, B.; Zard, S. Z. Acc. Chem. Res. 2015, 48 1237-1253. doi:10.1021/acs.accounts.5b00019

7. Zard, S. Z. J. Phys. Org. Chem. 2012, 25, 953-964. doi:10.1002/poc.2976

8. Quiclet-Sire, B.; Zard, S. Z. Chimia 2012, 66, 404-412. doi:10.2533/chimia.2012.404

9. Quiclet-Sire, B.; Zard, S. Z. Pure Appl. Chem. 2011, 83, 519-551. doi:10.1351/pac-con-10-08-07

10. Quiclet-Sire, B.; Zard, S. Z. Top. Curr. Chem. 2006, 264, 201-236. doi:10.1007/128_029

11. Quiclet-Sire, B.; Zard, S. Z. Chem. - Eur. J. 2006, 12, 6002-6016. doi:10.1002/chem.200600510

12.Zard, S. Z. Aust. J. Chem. 2006, 59, 663-668. doi:10.1071/ch06263

13. Zard, S. Z. Angew. Chem., Int. Ed. Engl. 1997, 36, 672-685. doi:10.1002/anie.199706721

14. Czaplyski, W. L.; Na, C. G.; Alexanian, E. J. J. Am. Chem. Soc. 2016, 138, 13854-13857. doi:10.1021/jacs.6b09414
15. Perrier, S. Macromolecules 2017, 50, 7433-7447. doi:10.1021/acs.macromol.7b00767

16. Chiefari, J.; Chong, Y. K.; Ercole, F.; Krstina, J.; Jeffery, J.; Le, T. P. T.; Mayadunne, R. T. A.; Meijs, G. F.; Moad, C. L.; Moad, G.; Rizzardo, E.; Thang, S. H. Macromolecules 1998, 31, 5559-5562. doi:10.1021/ma9804951

17. García-Merinos, J. P.; Hernández-Pérez, J. P.; Martínez-García, L.; Rojas-Lima, S.; López-Ruiz, H. J. Mex. Chem. Soc. 2007, 51, 209-212.

18. Boivin, J.; Nguyen, V. T. Beilstein J. Org. Chem. 2007, 3, No. 45. doi:10.1186/1860-5397-3-45

19. Charrier, N.; Gravestock, D.; Zard, S. Z. Angew. Chem., Int. Ed. 2006, 45, 6520-6523. doi:10.1002/anie.200601567

20. Jean-Baptiste, L.; Yemets, S.; Legay, R.; Lequeux, T. J. Org. Chem. 2006, 71, 2352-2359. doi:10.1021/jo052528y

21. Briggs, M. E.; Zard, S. Z. Synlett 2005, 334-336. doi:10.1055/s-2004-837191

22. Tazhe Veetil, A.; Šolomek, T.; Ngoy, B. P.; Pavlíková, N.; Heger, D.; Klán, P. J. Org. Chem. 2011, 76, 8232-8242. doi:10.1021/jo201385b

23. Ferjančić, Z.; Čeković, Ž.; Saičić, R. N. Tetrahedron Lett. 2000, 41, 2979-2982. doi:10.1016/s0040-4039(00)00286-0

24. Maslak, V.; Čeković, Ž.; Saičić, R. N. Synlett 1998, 1435-1437. doi:10.1055/s-1998-1946

25. Mestre, F.; Tailham, C.; Zard, S. Z. Heterocycles 1989, 28, 171-174. doi:10.3987/com-88-s77

26. Delduc, P.; Tailhan, C.; Zard, S. Z. J. Chem. Soc., Chem. Commun. 1988, 308-310. doi:10.1039/c39880000308

27. López-Mendoza, P.; Díaz, J. E.; Loaiza, A. E.; Miranda, L. D. Tetrahedron 2018, 74, 5494-5502. doi:10.1016/j.tet.2018.04.079

28. Twilton, J.; Le, C.; Zhang, P.; Shaw, M. H.; Evans, R. W.; MacMillan, D. W. C. Nat. Rev. Chem. 2017, 1, No. 0052. doi:10.1038/s41570-017-0052

29. Cambié, D.; Bottecchia, C.; Straathof, N. J. W.; Hessel, V.; Noël, T. Chem. Rev. 2016, 116, 10276-10341. doi:10.1021/acs.chemrev.5b00707

30. Romero, N. A.; Nicewicz, D. A. Chem. Rev. 2016, 116, 10075-10166. doi:10.1021/acs.chemrev.6b00057

31. Skubi, K. L.; Blum, T. R.; Yoon, T. P. Chem. Rev. 2016, 116, 10035-10074. doi:10.1021/acs.chemrev.6b00018

32. Ravelli, D.; Protti, S.; Fagnoni, M. Chem. Rev. 2016, 116, 9850-9913. doi:10.1021/acs.chemrev.5b00662

33. Kärkäs, M. D.; Porco, J. A., Jr.; Stephenson, C. R. J. Chem. Rev. 2016, 116, 9683-9747. doi:10.1021/acs.chemrev.5b00760

34. Shaw, M. H.; Twilton, J.; MacMillan, D. W. C. J. Org. Chem. 2016, 81, 6898-6926. doi:10.1021/acs.joc.6b01449

35. Corrigan, N.; Shanmugam, S.; Xu, J.; Boyer, C. Chem. Soc. Rev. 2016, 45, 6165-6212. doi:10.1039/c6cs00185h

36. Prier, C. K.; Rankic, D. A.; MacMillan, D. W. C. Chem. Rev. 2013, 113, 5322-5363. doi:10.1021/cr300503r

37. Narayanam, J. M. R.; Stephenson, C. R. J. Chem. Soc. Rev. 2011, 40, 102-113. doi:10.1039/b913880n

38. Ding, C.; Fan, C.; Jiang, G.; Pan, X.; Zhang, Z.; Zhu, J.; Zhu, X. Macromol. Rapid Commun. 2015, 36, 2181-2185. doi:10.1002/marc.201500427

39. Shanmugam, S.; Xu, J.; Boyer, C. Macromolecules 2014, 47, 4930-4942. doi:10.1021/ma500842u

40. Xu, J.; Jung, K.; Atme, A.; Shanmugam, S.; Boyer, C. J. Am. Chem. Soc. 2014, 136, 5508-5519. doi:10.1021/ja501745g

41. Phommalysack-Lovan, J.; Chu, Y.; Boyer, C.; Xu, J. Chem. Commun. 2018, 54, 6591-6606. doi:10.1039/c8cc02783h 
42. Huang, Z.; Noble, B. B.; Corrigan, N.; Chu, Y.; Satoh, K.; Thomas, D. S.; Hawker, C. J.; Moad, G.; Kamigaito, M.; Coote, M. L. Boyer, C.; Xu, J. J. Am. Chem. Soc. 2018, 140, 13392-13406. doi:10.1021/jacs.8b08386

43. Aerts, A.; Lewis, R. W.; Zhou, Y.; Malic, N.; Moad, G.; Postma, A. Macromol. Rapid Commun. 2018, 39, 1800240. doi:10.1002/marc. 201800240

44. Fu, C.; Huang, Z.; Hawker, C. J.; Moad, G.; Xu, J.; Boyer, C. Polym. Chem. 2017, 8, 4637-4643. doi:10.1039/c7py00713b

45. Xu, J.; Fu, C.; Shanmugam, S.; Hawker, C. J.; Moad, G.; Boyer, C. Angew. Chem., Int. Ed. 2017, 56, 8376-8383. doi:10.1002/anie.201610223

46. Teegardin, K.; Day, J. I.; Chan, J.; Weaver, J. Org. Process Res. Dev. 2016, 20, 1156-1163. doi:10.1021/acs.oprd.6b00101

47. Lowry, M. S.; Goldsmith, J. I.; Slinker, J. D.; Rohl, R.; Pascal, R. A.; Malliaras, G. G.; Bernhard, S. Chem. Mater. 2005, 17, 5712-5719. doi:10.1021/cm051312+

48. Shen, T.; Zhao, Z.-G.; Yu, Q.; Xu, H.-J. J. Photochem. Photobiol., A 1989, 47, 203-212. doi:10.1016/1010-6030(89)87066-2

49. Du, Y.; Pearson, R. M.; Lim, C.-H.; Sartor, S. M.; Ryan, M. D.; Yang, H.; Damrauer, N. H.; Miyake, G. M. Chem. - Eur. J. 2017, 23, 10962-10968. doi:10.1002/chem.201702926

50. Singh, A.; Teegardin, K.; Kelly, M.; Prasad, K. S.; Krishnan, S.; Weaver, J. D. J. Organomet. Chem. 2015, 776, 51-59. doi:10.1016/j.jorganchem.2014.10.037

51. Strieth-Kalthoff, F.; James, M. J.; Teders, M.; Pitzer, L.; Glorius, F. Chem. Soc. Rev. 2018, 47, 7190-7202. doi:10.1039/c8cs00054a

52. Xiao, W.-J.; Zhou, Q.-Q.; Zou, Y.-Q.; Lu, L.-Q. Angew. Chem., Int. Ed. 2018. doi:10.1002/anie.201803102

53. Teders, M.; Henkel, C.; Anhäuser, L.; Strieth-Kalthoff, F.; Gómez-Suárez, A.; Kleinmans, R.; Kahnt, A.; Rentmeister, A.; Guldi, D.; Glorius, F. Nat. Chem. 2018, 10, 981-988. doi:10.1038/s41557-018-0102-z

54. van As, D. J.; Connell, T. U.; Brzozowski, M.; Scully, A. D.; Polyzos, A. Org. Lett. 2018, 20, 905-908. doi:10.1021/acs.orglett.7b03565

55. Ichimura, K.; Kobayashi, T.; King, K. A.; Watts, R. J. J. Phys. Chem. 1987, 91, 6104-6106. doi:10.1021/j100308a012

56. Coyle, J. D. Tetrahedron 1985, 41, 5393-5425. doi:10.1016/s0040-4020(01)91341-9

57. Cismesia, M. A.; Yoon, T. P. Chem. Sci. 2015, 6, 5426-5434. doi:10.1039/c5sc02185e

58. Hatchard, C. G.; Parker, C. A. Proc. R. Soc. London, Ser. A 1956, 235 , 518-536. doi:10.1098/rspa.1956.0102

59. Studer, A.; Curran, D. P. Angew. Chem., Int. Ed. 2016, 55, 58-102. doi:10.1002/anie.201505090

60. Christmann, J.; Ibrahim, A.; Charlot, V.; Croutxé-Barghorn, C.; Ley, C.; Allonas, X. ChemPhysChem 2016, 17, 2309-2314. doi:10.1002/cphc.201600034

61. Arceo, E.; Montroni, E.; Melchiorre, P. Angew. Chem., Int. Ed. 2014, 53, 12064-12068. doi:10.1002/anie.201406450

62. Devery, J. J., III; Nguyen, J. D.; Dai, C.; Stephenson, C. R. J. ACS Catal. 2016, 6, 5962-5967. doi:10.1021/acscatal.6b01914

63. Kim, H.; Lee, C. Angew. Chem., Int. Ed. 2012, 51, 12303-12306. doi:10.1002/anie.201203599

64. Quiclet-Sire, B.; Zard, S. Z. Org. Lett. 2008, 10, 3279-3282. doi:10.1021/ol801162m

65. Gagosz, F.; Zard, S. Z. Org. Lett. 2003, 5, 2655-2657. doi:10.1021/ol034812m

\section{License and Terms}

This is an Open Access article under the terms of the Creative Commons Attribution License (http://creativecommons.org/licenses/by/4.0). Please note that the reuse, redistribution and reproduction in particular requires that the authors and source are credited.

The license is subject to the Beilstein Journal of Organic Chemistry terms and conditions:

(https://www.beilstein-journals.org/bjoc)

The definitive version of this article is the electronic one which can be found at:

doi:10.3762/bjoc. 14.283 